\title{
IGF1R Gene Alterations in Small for Gestational Age (SGA) Children
}

\author{
Aleksandra Janchevska $^{1^{*}}$, Aleksandar Dimovski $^{2}$, Kristina Mironska $^{1}$, Velibor Tasic ${ }^{1}$, Zoran Gucev $^{1}$ \\ ${ }^{1}$ University Children's Hospital, Faculty of Medicine, Ss Cyril and Methodius University of Skopje, Skopje, Republic of \\ Macedonia; ${ }^{2}$ Macedonian Academy of Sciences and Arts, Skopje, Republic of Macedonia
}

Abstract

Citation: Janchevska A, Dimovski A, Mironska K, Tasic $V$, Gucev Z. IGF1R Gene Alterations in Small for Gestational Age (SGA) Children. Open Access Maced Med Sci. 2018 May 20; 6(5):790-793.

Keywords: SGA born children; Microcephaly; Shor stature; Exon 2 of IGF1R gene; Gene analysis

*Correspondence: Aleksandra Janchevska. University Children's Hospital, Faculty of Medicine, Ss Cyril and Methodius University of Skopje, Skopje, Republic of Macedonia. E-mail: dr.sasha1969@yahoo.com

Received: 04-Apr-2018; Revised: 04-May-2018; Accepted: 09-May-2018; Online first: 13-Jun-2018

Copyright: ๑ 2018 Aleksandra Janchevska, Aleksandar Dimovski, Kristina Mironska, Velibor Tasic, Zoran Gucev. This is an open-access article distributed under the terms of the Creative Commons Attribution-NonCommercial 4.0 International License (CC BY-NC 4.0)

Funding: This research did not receive any financia

support

Competing Interests: The authors have declared that no competing interests exis

\begin{abstract}
BACKGROUND: Small for gestational age children (SGA) is born on term with BW and or BL of -2.0 standard deviation score (SDS). SGA children have an increased risk of being short, developing DM, and cardiovascular and cerebrovascular disease. Often defects of IGF1R are the cause of SGA. Most frequently affected part of the IGF1R gene is the exon 2 .

AIM: To investigate whether the exon 2 of the IGF1R gene is affected in the SGA children.

PATIENTS AND METHODS: A cohort of 100 SGA children born in term was evaluated for alterations in IG1 $R$ gene. Their anthropometric parameters, IGF1 serum concentrations and IGF1 SDS values were analysed. The molecular analysis of IGF1R gene was performed by PCR restriction-site analysis and followed by direct sequencing of conspicuous fragments.

RESULTS: Within our cohort, 64 SGA children were with short stature (height SDS $-3.25 \pm 0.90$ SDS), and 36 were with normal height for their age and sex, (H SDS was $0.20 \pm 1.1$ SDS). None of these children had microcephaly (occipitofrontal circumference $-0.70 \pm 1.01$ SDS vs $0.06 \pm 0.56$ SDS in SGA children with norma height) or dysmorphic features. The IGF1 serum concentrations and IGF1 SDS values of all children were within normal range. Only one child had lower normal serum IGF1 concentration. No alterations in exon 2 of IGF1R gene were detected.
\end{abstract}

CONCLUSIONS: The genetic analysis of the exon 2 of the IGF1R gene did not detect any gene defects in the analysed patients. The putative genetic defect in those children affects other parts of the IGF1R gene or another gene (s), or yet unidentified factors.

\section{Introduction}

SGA children comprise $3 \%$ of all births. Those are the children with birth weight (BW) and/or birth length (BL) less than 2.0 standard deviation score (SDS). Only $10 \%$ of children do not attain normal height until the age of four or five years. In fact, that $10 \%$ have a higher risk to remain short, as well as increased prone to diabetes mellitus, cerebrovascular and cardiovascular diseases in adulthood [1].

The aetiology of SGA is heterogeneous. Genetic factors are a culprit in some of them. Defects in IGF1R gene are reported as a cause of SGA [2] [3]
[4]. The most affected part of the IGF1R gene is its exon 2.

Insulin-like growth factor 1 receptor (IGF1R) is a heterotetrameric ( $\alpha 2 \beta 2)$ transmembrane glycoprotein with intrinsic kinase moiety. It contains 2 alfa and two beta subunits synthetized by one mRNA precursor ( $\alpha 2 \beta 2$ ). IGF-1R and IR (insulin receptor) are parts of the same family together with IGF-2R and their ligands IGF-1 and IGF-2 and at least 6 IGFbinding proteins, so-called protein kinase superfamily or tyrosine protein kinase family and insulin receptor subfamily [5] [6] [7] [8]. GF1R and IR receptors are found in skeletal muscles, heart, kidneys, fat tissue, liver, spleen, fibroblasts and placenta. 
We investigated the exon 2 of the IGF-1R gene, as this gene part is the often affected by nucleotide alterations. 100 SGA children were analysed. a z-test is used, otherwise a t-test. All tests are with a $99 \%$ significance or $\alpha=0.01$.

\section{Results}

\section{Patients and Methods}

The cohort of $100(\mathrm{M}: \mathrm{F}=40: 60)$ children born in term ( $\geq 37 \mathrm{GW})$, but small for gestational age is composed of two groups: a group of $64(\mathrm{M}: \mathrm{F}=31: 33)$ SGA born children who did not achieve catch-up growth after the 2nd year and remained short and a group of 36 (M:F = 13:23) SGA born children (older than 4 years) with normal growth spurts for their age and sex.

Anthropometric data and IGF-1 concentrations were evaluated. IGF1-BP3 was not available. Clinical birth data include children's birth weight (BW) in kilograms, BW standard deviation score (SDS), birth length (BL) in centimetres, BL SDS and gestation week (GW). Also, the height SDS, weight SDS, occipitofrontal circumference SDS, body mass index (BMI), BMI z-score and target height (TH) SDS were also analysed.

The serum concentrations of Insulin-like growth factor 1 (IGF1) were determined by chemiluminescence immune assay method on IMMULITE 2000 Siemens, Immunoassay System apparatus.

The molecular analysis of IGF1R gene was performed on ("Biometra"-T3 Thermocycler PCR apparatus) in Laboratory for Molecular medicine in University Children's Hospital Skopje. Start DNA material was isolated from leukocytes with high concentrated $5 \mathrm{M} \mathrm{NaCl}$ solution. This genomic DNA material of particular exon 2 was amplified using the polymerase chain reaction (PCR) to perform the restriction-site analysis. We used following primers: 5'TCGACATCCGCAACGACTATC3' as the forward primer and the 5'CGAAGATGACCAGGGCGTAG3' as reverse primer. PCR products were digested with Dde I (Sigma Aldrich), and the resulting fragments were characterized by $1 \%$ agarose gel horizontal electrophoresis and staining with ethidium bromide. PCR products of coding IGF1R exon 2 were screened by direct sequencing of conspicuous fragments in Molecular Laboratory of Faculty of Pharmacy.

The Kolmogorov-Smirnov test (KS test) is used to check whether the values have a normal (Gaussian) distribution. A confidence interval $(\mathrm{Cl})$ is calculated for the mean of each of the quantities. For the comparison of 2 groups, Fisher's test is used to check the equivalence of variances. The result of this test is relevant for applying the test for equivalence of means. If the 2 samples have a size greater than 30 ,

The mean birth weight (BW) and BW standard deviation score (BW SDS), birth length (BL) and $\mathrm{BL}$ SDS were: in 64 short children BW $2284.37 \mathrm{gr} \pm 433$ SDS and BW SDS $-2.71 \pm 1.05$ SDS, BL $47.06 \pm 2.09$ SDS and BL SDS $-1.33 \pm 1.03$ SDS and in 36 children with normal height BW $2502.5 \mathrm{gr} \pm 317.8$ SDS and BW SDS $-2.15 \pm$ SDS and BL $46.63 \mathrm{~cm} \pm 2.12$ SDS and BL SDS $-1.61 \pm 1.12$ SDS (Table 1).

Table 1: Birth parameters: Birth weight (BW), BW SDS, birth length (BL), BL SDS and Gestation Week (GW) in 2 groups of children: a group of 64 short SGA born children and group of 36 SGA born children with normal height

\begin{tabular}{|c|c|c|c|c|c|c|}
\hline \multicolumn{2}{|l|}{ Groups } & $\begin{array}{l}\text { Short SGA } \\
\text { Children }\end{array}$ & \multicolumn{3}{|c|}{$\begin{array}{l}\text { SGA children with } \\
\text { Normal height }\end{array}$} & $\begin{array}{l}\text { Comparison } \\
\text { Between } \\
\text { Two groups }\end{array}$ \\
\hline \multicolumn{2}{|c|}{ Parameters } & Mean & $\begin{array}{c}\text { P- } \\
\text { value } \\
\text { From } \\
\text { Ks test }\end{array}$ & Mean & $\begin{array}{l}\text { P-value } \\
\text { From } \\
\text { Ks test }\end{array}$ & P-value \\
\hline$\overline{B W}$ & Gr & $2284.37 \pm 433$ SDS & 0.18 & $2502.5 \pm 317.8$ SDS & 0.97 & 0.0095 \\
\hline BW SDS & - & $-2.71 \pm 1.05$ SDS & 0.78 & $-2.15 \pm 0.56 \mathrm{SDS}$ & 0.48 & 0.0009 \\
\hline BL & $\mathrm{Cm}$ & $47.06 \pm 2.09$ SDS & 0.56 & $46.63 \pm 2.12$ SDS & 0.87 & 0.33 \\
\hline BL SDS & - & $-1.33 \pm 1.03$ SDS & 0.34 & $-1.61 \pm 1.12$ SDS & 0.93 & 0.22 \\
\hline GW & W & $39.17 \pm 0.94$ SDS & 0.46 & $39.34 \pm 0.90$ SDS & 0.61 & 0.37 \\
\hline Patients & M & $\mathrm{N}=31$ & & $\mathrm{~N}=13$ & & \\
\hline & & $\mathrm{N}=33$ & & $\mathrm{~N}=23$ & & \\
\hline
\end{tabular}

Short children had measured height SDS $(\mathrm{H}$ SDS) $(-3.25 \pm 0.90$ SDS), weight SDS (W SDS) $(-2.72$ \pm 1.39 SDS $)$, BMI z-score $(0.88 \pm 1.78$ SDS $)$ and occipitofrontal circumference SDS (OFC SDS) (-0.70 $\pm 1.01 \mathrm{SDS}$ ) at the time of entrance the study. Growth parameters of children with caught up growth were: $\mathrm{H}$ SDS $(0.20 \pm 1.1$ SDS $)$, W SDS $(0.29 \pm 1.53$ SDS $)$, BMl z-score $(0.01 \pm 1.68 \mathrm{SDS})$ and OFC SDS (0.06 \pm 0.56 SDS) (Table 2).

Table 2: Auxology parameters: height SDS (H SDS), weight SDS (W SDS), BMI and BMI z-score, occipitofrontal circumference SDS (OFC SDS), Target Height SDS (TH SDS) in 2 groups of children: a group of 64 short SGA born children and group of 36 SGA born children with normal height

\begin{tabular}{|c|c|c|c|c|c|c|}
\hline \multicolumn{2}{|l|}{ Groups } & \multicolumn{2}{|c|}{$\begin{array}{l}\text { Short SGA } \\
\text { Children }\end{array}$} & \multicolumn{2}{|c|}{$\begin{array}{l}\text { SGA children with } \\
\text { Normal height }\end{array}$} & $\begin{array}{l}\text { Comparison } \\
\text { Between } \\
\text { Two groups }\end{array}$ \\
\hline Parameters & & Mean & $\begin{array}{l}\text { P-value } \\
\text { From } \\
\text { Ks test }\end{array}$ & Mean & $\begin{array}{c}\text { P- } \\
\text { value } \\
\text { From } \\
\text { Ks test }\end{array}$ & P-value \\
\hline HSDS & - & $-3.25 \pm 0.90$ SDS & 0.19 & $0.20 \pm 1.1$ SDS & 0.62 & 0.024 \\
\hline W SDS & - & $-2.72 \pm 1.39$ SDS & 0.45 & $0.29 \pm 1.53$ SDS & 0.65 & $3.30 \mathrm{e}-16$ \\
\hline BMI & $\mathrm{Kg} / \mathrm{m}^{2}$ & $15.25 \pm 2.15$ SDS & 0.41 & $17.28 \pm 4.39$ SDS & 0.14 & 0.012 \\
\hline $\begin{array}{l}\text { BMI Z- } \\
\text { SCOBE }\end{array}$ & - & $-0.88 \pm 1.78$ SDS & 0.31 & $0.01 \pm 1.68$ SDS & 0.70 & 0.015 \\
\hline OFC SDS & - & $-0.70 \pm 1.01$ SDS & 0.91 & $0.06 \pm 0.56$ SDS & 0.95 & $3.82 \mathrm{e}-06$ \\
\hline TH SDS & - & $-1.00 \pm 0.87$ SDS & 0.52 & $0.15 \pm 0.91$ SDS & 0.98 & $6.98 \mathrm{e}-9$ \\
\hline
\end{tabular}

None of our SGA born children had dysmorphic features.

Only in one boy with short stature (-2.63 SDS) had low normal IGF1 serum concentration (52.3 
$\mathrm{ng} / \mathrm{ml}, \mathrm{N}=50-286)$ and IGF1 SDS (-1.57 SDS) for his age and sex. The PCR restriction-site analysis in all SGA born children did not show any genetic alteration in exon 2 of IGF1R gene. The screened PCR products coding IGF1R exon 2 by direct sequencing of conspicuous fragments were uneventful.

\section{Discussion}

Several alterations (point mutations and deletions) in the IGF1 and insulin-like growth factor 1 receptor (IGF-1R) genes have been demonstrated last decade. Alterations have been identified that affect IGF1R biosynthesis, signal reception and receptor kinase activity [9] [10] [11] [12] [13] [14] [15] [16] [17] [18] [19].

Homozygous defects in the IGF1 gene have been found in patients with major developmental impairments and severe intrauterine and postnatal growth retardation. On the other hand, mutations in IGF1R gene that have been predominantly heterozygous are 3 found in patients with mild phenotype and clinically heterogeneous presentation [20].

Since 2003y Abuzzahab et al., [10] described 2 point mutations in exon 2 of IGF1R gene: the first was compound heterozygosity with the exchange of arginine by glutamine at amino acid 108 (p. R108Q) and exchange for lysine by asparagine in the amino acid 115 (p. K115N) in SGA born girl with delayed motor development, psychiatric problems and growth retardation. The authors also described another heterozygous mutation in the éxon 2 (p. R89X) in an IUGR born boy with microcephaly, short stature and delayed motor and speech development.

Kawashima et al., [11] in 2005 described missense mutation in heterozygosity at 11 éxon the IGF1R (p. R739Q) in a SGA born patient with significant mental retardation and postnatal growth. In SGA born 35 y old patient with microcephaly and elevated IGF1 values, Walenkamp et al., [12] 2006y found a mutation in the éxon 16 (p. E1050K). Inagaki et al., [13] 2007y found heterozygous point mutation resulting in R481Q in a girl with short stature and elevated IGF1 values. Kruis et al., 2010y [14] in 7 members of the same family with low BW, microcephaly and normal mental development, reported similar mutation which resulted in G1125A protein.

Wallborn et al., [15] found a mutation of IGF1R gene p. V599E in SGA born patient with microcephaly, mental retardation and elevated IGF1 levels. Fang et al., 2009 [16] reported novel heterozygous 19 nucleotides duplication within 18 éxon of IGF1R gene and consequently to haploinsufficiency of IGF1R protein in 4 short statured family members with normal IGF1 levels. Mohn et al., 2011 [17] described 4 SGA family members with short stature and impaired glucose metabolism with a novel mutation (p.Tyr387X).

Labarta et al., 2013 [21] described novel heterozygous IGF1R missense mutation in exon 7 (c.A1549T, p.Y487F) in 3 IUGR born females from the same family with short stature and microcephaly. Juanes et al., [22] 2015 identified three novel heterozygous missense mutations in 3 patients with microcephaly and growth retardation, de novo p.Arg1256Ser, de novo p.Asn359Tyr and p.Tyr865Cys.

We investigated 100 SGA born children, 64 children were with short stature -H SDS $(-3.25 \pm 0.90$ SDS) and 36 children with normal height $-H$ SDS $(0.20 \pm 1.1$ SDS). They were born with low BW SDS ($2.71 \pm 1.05 \mathrm{SDS})$ vs $(-2.15 \pm 0.56 \mathrm{SDS})$ and/or $\mathrm{BL}$ SDS $(-1.33 \pm 1.03$ SDS) vs $(-1.61 \pm 1.12$ SDS $)$. No alterations in exon 2 of the IGF1R gene were found.

The IGF1 serum concentration only in one patient of our cohort was in the lower normal range for his age and sex at the time of diagnosis. The defects of IGF1R usually result in elevated IGF1 serum concentrations [2] [12] [13] [15].

In conclusion, within a cohort of 100 SGA born children without microcephaly or dysmorphic features we did not find alterations in the exon 2 of the IGF1R gene. Exon 2 of the IGF1R gene might not be a hotspot for alterations. Investigating most or the whole of the IGF1R gene together with other genes implicated in SGA might yield an answer on the SGA cause of a particular child.

\section{References}

1. Lee PA, Chernausek SD, Hokken-Koelega AC, Czernichow P. International Small for Gestational Age Advisory Board consensus development conference statement: management of short children born small for gestational age, April 24-October 1, 2001. Paediatrics. 2003; 111(6):1253-61.

https://doi.org/10.1542/peds.111.6.1253 PMid:12777538

2. Pfäffle R, Kiess W, Klammt J. Downstream insulin-like growth factor. In Developmental Biology of GH Secretion, Growth and Treatment. 2012; 23:42-51. https://doi.org/10.1159/000341745 PMid:23182819

3. Randhawa RS. The insulin-like growth factor system and fetal growth restriction. Pediatr Endocrinol Rev. 2008; 6(2):235-240. PMid:19202510

4. Kawashima Y, Takahashi S, Kanzaki S. Familial short stature with IGF-I receptor gene anomaly. Endocr J. 2012; 59(3):179-185. https://doi.org/10.1507/endocri.EJ11-0258 PMid:22008389

5. Vashisth $\mathrm{H}$, Abrams CF. All-atom structural models for complexes of insulin-like growth factors IGF1 and IGF2 with their cognate receptor. Journal of Molecular Biology. 2010, 400(3):645658. https://doi.org/10.1016/j.jmb.2010.05.025 PMid:20488191

6. Abbot A, Buenos R, Pedrini MT, Murray JM, Smith RJ. Insulin - 
like growth factor I receptor gene structure. The J Biol Chem. 1992; 267: 10759-10763.

7. Cooke DW, Bankert LA, Roberts CT Jr, LeRoith D, Casella SJ. Analysis of the human type I insulin-like growth factor receptor promoter region. Biochem Biophys Res Commun. 1991; 177(3):1113-1120. https://doi.org/10.1016/0006-291X(91)90654-P

8. Ullrich A, Gray A, Tam WA, Yang-Feng T, Tsubokawa M, Collins $C$ et al. Insulin-like growth factor I receptor primary structure: comparison with insulin receptor suggests structural determinants that define functional specificity. The EMBO Journal. 1986; 10:2503-2512.

9. Saenger P, Reiter E. Genetic factors associated with small for gestational age birth and the use of human growth hormone in treating the disorder. Int J Pediatr Endocrinol. 2012; 2012(1):12. https://doi.org/10.1186/1687-9856-2012-12 PMid:22587301 PMCid:PMC3511163

10. Abuzzahab MJ, Schneider A, Goddard A, Grigorescu F, Lautier $\mathrm{C}$, Keller E, et al. IGF-I receptor mutations resulting in postnatal growth retardation intrauterine and. N Engl J Med. 2003; 349 (23):2211-22. https://doi.org/10.1056/NEJMoa010107 PMid:14657428

11. Kawashima Y, Kanzaki's, Yang F, Kinoshita T, Hanaki K, Nagaishi J, et al. Mutation at cleavage site of insulin-like growth factor receptor in the short stature born intrauterine growth retardation with child. J Clin Endocrinol Metab. 2005; 90 (8): 467987. https://doi.org/10.1210/jc.2004-1947 PMid:15928254

12. Walenkamp MJ, van der Kamp HJ, Pereira AM, Kant SG, van Duyvenvoorde HA, Kruithof MF, et al. A variable intrauterine and postnatal growth degree of retardati-on in the family with the et mutation in the insulin-like growth factor I receptor. J Clin Endocrinol Metab. 2006; 91 (8): 3062-70. https://doi.org/10.1210/jc.2005-1597 PMid:16757531

13. Inagaki K, Tiulpakov A, Rubtsov $P$, Sverdlova $P$, Peterkova V, Yakar S, et al. The familial insulin-like growth factor I receptor mutant leads to short stature: clinical and biochemical characterization. J Clin Endocrinol Metab. 2007; 92 (4):1542-8. https://doi.org/10.1210/jc.2006-2354 PMid:17264177

14. Kruis T, Klammt J, Tsinopoulou A, Galli-Wallborn T, Muller M and Schlicke et al. Heterozygous mutation within the kinaseconserved motif of the insulin-like growth factor I receptor intrauterine and postnatal growth retardation causes. J Clin Endocrinol Metab. 2010; 95(3):1137-1142.

https://doi.org/10.1210/jc.2009-1433 PMid:20103656

15. Wallborn T, Wuller S, Klammt J, Kratzsch T, Kruis J, Schmidt $\mathrm{G}$, et al. A heterozygous mutation of the insulin-like growth factor-I receptor causes retention of the protein in the endoplasmic reticulum and results in intrauterine and postnatal growth results in retardation. J Clin Endocrinol Metab. 2010; 95 (5): 2316-24. https://doi.org/10.1210/jc.2009-2404 PMid:20357178

16. Fang P, Schwartz ID, Johnson BD, Derr MA, Roberts Jr, Hwa CT V, et al. Familial short stature caused by haploinsufficiency of the insulin-like growth factor i receptor due to nonsense-mediated messenger ribonucleic acid decay. J Clin Endocrinol Metab. 2009; 94 (5):1740-7. https://doi.org/10.1210/jc.2008-1903 PMid:19240156

17. Mohn A, Marcovecchio ML, Giorgis T, Pfaeffle R, Chiarelli F, Kiess W. An insulin-like growth factor-I receptor defect associated with short stature and impaired carbohy-drate homeostasis in an Italian pedigree. Horm Res Paediatr. 2011; 76(2):136-43. https://doi.org/10.1159/000324957 PMid:21811077

18. Solomon-Zemler R, Basel-Vanagaite L, Steier D, Yakar S, Mel $\mathrm{E}$, Phillip $\mathrm{M}$ et al. A novel heterozygous IGF-1 receptor mutation associated with hypoglycemia. Endocr Connect. 2017; 6(6):395403. https://doi.org/10.1530/EC-17-0038 PMid:28649085 PMCid:PMC5551424

19. Mahmoud R, Naidu A, Risheg H, Kimonis V. Response to Growth Hormone Treatment in a Patient with Insulin-Like Growth Factor 1 Receptor Deletion. J Clin Res Pediatr Endocrinol. 2017; 9(4):380-386. https://doi.org/10.4274/jcrpe.4456 PMid:28720553 PMCid:PMC5785648

20. Caliebe J, Broekman S, Boogaard M, Bosch CA, Ruivenkamp CA, Oostdijk W et al. IGF1, IGF1R and SHOX mutation analysis in short children born small for gestational age and short children with normal birth size (idiopathic short stature). Horm Res Paediatr. 2012; 77(4):250-260. https://doi.org/10.1159/000338341 PMid:22572840

21. Labarta JI, Barrio E, Audí L, Fernández-Cancio M, Andaluz P, de Arriba $A$ et al. Familial short stature and intrauterine growth retardation associated with a novel mutation in the IGF-I receptor (IGF1R) gene. Clin Endocrinol (Oxf). 2013; 78(2):255-62. https://doi.org/10.1111/j.1365-2265.2012.04481.x PMid:22738321

22. Juanes M, Guercio G, Marino R, Berensztein E, Warman DM, Ciaccio $M$ et al. Three novel IGF1R mutations in microcephalic patients with prenatal and postnatal growth impairment. Clin Endocrinol (Oxf) 2015; 82(5):704-711. https://doi.org/10.1111/cen.12555 PMid:25040157 